\title{
Examination of Cultural Anthropology in Esfarayen's Oral Literature
}

\author{
Maryam Shokri \\ Department of Educational Administration, center tehran branch, Islamic Azad university, tehran, Iran \\ m.shokri1362@gmail.com
}

\section{Fariba Mereskandari}

Member of Faculty Educational Science, center tehran branch, Islamic Azad university, tehran, Iran

F_mireskandari@yahoo.com

\section{Doi:10.5901/mjss.2016.v7n3s2p86}

\section{Abstract}

The present study was aimed to examine people's oral literature in Esfarayen, an old city located in North Khorasan. Esfarayen possesses unique characteristics and a special culture with a rich oral literature, because it receives different races and tribes, especially Karmanji Kurds, Turks, Tats, and Persians, coming from different parts of Iran. Esfarayen's oral literature like in other parts of Iran is the product of mental, spiritual conditions based on dreams, failures, hopes, fears, and struggles in different areas of work such as agriculture and livestock. People in Esfarayen use oral literature for security, peace, survival, recreation, cultural affairs, and daily tasks; their oral literature includes vocals, anecdotes, lullabies, beliefs, superstitions, quotations, curses, prayers, and dreams. It should be noted that no study has been conducted with this approach. Being native and being an MA student, and more importantly, paying attention to people's oral literature have been the reasons why the author has selected this subject in the field of cultural anthropology. This research, using two study methods, has tried to gather, classify, analyze, and describe a considerable portion of people's oral literature in Esfarayen. The results obtained from show that ideas and linguistic and cultural differences help to reinforce people's culture in Esfarayen. Vocals, beliefs, superstitions, music, Iullabies, fortunes, legends, stories, and anecdote in Esfarayen are taken from people's dreams based on history. This thesis has been provided by relying on a field and documentary research method (interview, corporate observation) and using a theoretical framework of functionalism, diffusionism, and interpretivism.

Keywords: culture, folklore, Esfarayen, oral literature

\section{Introduction}

Human as a sociable creature is active in all dimensions of life; this activity includes both a materialistic and a nonmaterialistic aspect. One of the most important unusual crafts made by humans is "culture".

Culture is a set of awareness (knowledge) and technical, economical, religious, social, and customary behaviors which form a certain society (Panouf \& Pern, 2007, 2008).

Oral literature consists of myths, stories, beliefs, proverbs, idioms, and enigmas which are cultural elements in Esfarayen, each of which can fulfill a certain need. By carefully analyzing and interpreting them, it is possible to discover the different angles of people's lives as well as their feelings in the past. Fast cultural changes in all life areas have considerably influenced public culture in Esfarayen; and its elements and functions are being increasingly forgotten. However, other cultural elements such as idioms and proverbs are still popular with people in Esfarayen and continue to exist. In order to make their speeches sweeter or more serious, they use many idioms and proverbs, which is a characteristic of Kurdish dialect.

From among speech traditions, we can refer to fables which are plentiful. They can be recognized through their heroes, their role in social life, and concepts that are related to their styles. Hence, there are six types of fables:

"Public stories, heroes, legends, ballads, imaginations, epics, and non-narrative stories including vocals, enigmas, proverbs, dirges (Tayeb Osman, 1991, 50)."

"Spiritual heritage and narrative traditions, non-narrative traditions, play traditions which are passed on from generation to generation. Sometimes for oral literature, there are expressions such as public literature, tribal literature, and colloquial literature (Ghanavati, 2012, Articles 91 to 92)." 
One of the most important features of local stories and legends in Esfarayen, which are undoubtedly memorials of ancient times, is the battle between good and evil in the form of invisible creatures that have been mentioned in most legends. A content analysis for each of them can express the atmosphere of stories and thoughts ruling people's minds. Here, beliefs are the most important subject which is seen in most human life aspects especially in legends and stories. Normally, stories have good endings; and good characters (people and heroes) experience the good ending.

"Oral Literature is normally examined by folklorists and scientists such as linguists, anthropologists, and even sociologists who study cultures and tribal literature (Quarterly of the Iranian people's culture, 2006, 335).

Stories and legends like any other cultural element change over time; and this trend slows down or speeds up depending on needs and time conditions; but the format and layout of stories remains the same. This can be studied in different stories among people in bordering provinces. And it is possible to determine how a great portion of oral literature in Esfarayen can result from a unique extent.

In this paper, a field study method has been used with an interview and observation technique as well as a cooperative and library observation. Considering anthropology studies and oral literature in Esfarayen, a profound anthropology method was used through a direct cooperative observation. In the examination of oral literature anthropology, Esfarayen, Khorasan was selected as a study sample. In this study, we tried to gather and classify necessary information, using anthropology methods and their special tools. Some of the tools are: plan for determining a study range, recorder and filming devices for recording and videoing speakers, paper and pencils for taking important notes or for cases where recording is impossible.

\section{Research Goals}

Examining cultural anthropology aspects in people's oral literature in Esfarayen.

In order to realize the main goal of the study, it is possible to express smaller goals as follows:

1) Identification and analyzing people's oral literature in Esfarayen.

2) Examining the roots of people's oral literature in Esfarayen.

3) Examination and identification of the relationship between people's public literature in Esfarayen and daily lives and beliefs.

4) Examination and identification of people's oral literature functions in Esfarayen.

\subsection{Research Background}

Regarding oral literature in Esfarayen, unfortunately there isn't directly a book source, a thesis, or even magazines; but limited sources have referred to this indirectly; these sources are as follows:

"Esfarayen's geography", written by Seyed Ahmad Fadayi (1995), published by "Astan-e-Qods-e-Razavi, 255 pages. Esfarayen is a city in North Khorasan. Its center is Esfarayen. Safi Abad is another city in Esfarayen. The most important ancient monument in Esfarayen is the historical city of Belgheis. Citadel of Belgheis which is also referred to as Narin Castle in books is the most important historical monument in Esfarayen, which has been recorded as part of the historical city of Belgheis in the list of national works in 2001. In the third century, Esfarayen was very active as an important cultural center around Neishabour. In terms of age, the oldest residential periods in this place date back to the second half of the third century.

"Examination of Esfarayen's dialect", written by Baba Homayunfar, published by Chapar, 3000 books, in 2007. Dialects and collections of words and expressions in a language were phenomena that attracted the attention of linguists and grammarian. "The eighteenth century grammarians believed that literary adapted language, which is the language of high social classes, is older and is more consistent with micro adaption than with local languages whose existence is a sign of people's carelessness and stupidity. However, over time, grammarian understood that local dialects have maintained ancient properties in them, and there is no sign of them in other adapted languages. In the late eighteenth century, a number of dialect cultures came to existence over time, each of which expressed the properties of nonadapted speech.

"lullabies in the culture of people in Southern Khorasan", the title of Atusa Afsar's M.A. thesis which was written in Tehran's Central Islamic University, with the help of Dr. Asqar Asgari Khanghah, with consultation from Dr. Fariba Mir Eskandari in Sep, 2013, in the psychology and anthropology faculty of the Central Islamic University of Tehran. In their conclusion, they wrote that literature is a research which is in connection to the formation of oral literature, position of 
vocals and lullabies in literature, children's oral literature and the way it is transferred, children's poems, lullaby history, examination of lullabies as an emotional need for children, being rhythmic, elements forming lullabies, the reasons women sing lullabies, and the role of women in the maintenance and transference of cultural heritage, and the way they built cribs.

"Dance in two cultures: Armenian and Azeri", Shirin Rahimzadeh's thesis, entitled as "Dance in Armenia and Azerbaijan", defended in Tehran's Research and Science University, with the help of Dr. Mohammad Aref in 2015, concluded that the conditions and the political-social-geographical positions in two cultures, motives, concerns, and common conflicts between them regardless of differences, reactions, and their distances have similar impacts which can result in similar social moves and artistic phenomena.

"Anthropology of folkloric poems (local vocals) in Kashmar: Mohammad Forghani's thesis, tutor: Dr. Mohammad Homayun Sepehr. Researcher seeked to examine the culture and customs, beliefs, economy and relationships between local poems and vocals in Kashmar.

"Reference to anthropology in oral literature and written literature": In the social sciences thesis, no 11, there was a paper written by Kazem Ashkouri, with this title; in this paper, the effects of oral literature and samples of written literature among people have been mentioned.

\subsection{Research Theoretical Framework (Theoretical Doctrines)}

In this research, vocals and folkloric stories in Esfarayen have been studied. Researcher, using functionalism, analyzes the function of these cultural products in order to local users. In functionalism, Malinofski emphasizes that all cultural properties are to meet people's needs in the society, i.e. the function of a cultural property is defined as the ability to meet people's primary needs (Asgari Khanghah \& Kamali, 2001, 260). In this paper, functionalism, diffusionism and interpretivism are used.

\subsubsection{Functionalism}

Functional analysis is not limited to anthropology; this method in behavioral science, medicine, and physics is of great importance; on the other hand, functionalism of architecture and the designs of contemporary homes are considered as the optimal use of construction tools. However, in anthropology, a primary function is in congruence with Radcliff Brown, Malinofski, and their followers. On the whole, it can be said that there are two inferences from functionalism: 1) the ultimate dimension of inference or functional ontology or functionalism ontology in the meaning of existential purpose for anything; hence, the existential purpose of a knife is its cutting ability. Indeed, the observation of such purposes in the context of materialistic culture is easier. For instance, in a museum, we can install questions as to: What is this object used for? Or what can this object do? This way, it is possible to figure out the functions of tools and to consider the sustenance of the society using the tools. The second inference of functionalism refers to the concept of interdependency. Interdependency shows how the elements of a whole interact and how they have been formed in order to maintain a whole (Farbod, 2009, 91).

In the following, a definition of Malinofski related to functionalism has been presented.

Functionalism is called Branislav Malinofski. We primarily present a definition offered by Malinofski: Function is meeting a need through an act whose purpose is to identify mutual contacts between elements which form it. He is the main founder and theorist of functionalism. He believes that any factor in a civilization and culture has an effect on the whole, and its function is to meet needs (Fakouhi, 2008, 76).

About functionalism, Dr. Farbod stated:

"I believe that functionalism can be the examination of any social act or any essence, considering the relationship that it has with all the society. For example, the study of a social custom is complete if its relationship with economy, politics, family, religion is considered (Farbod, 2009, 120).

Function in other European languages has a different meaning. But it generally means close advantage; for instance, pencils are used for writing; therefore, function, work, or use of a pencil is writing. In mathematics, funcsion means "Function" For example, it is said that (x) is a function of (y); or that "x" changes subject to "y". In cultural sociology and anthropology, the term "function" is used in its mathematical meaning. For example, the level of their presence in nature is a function of humans' abilities; or the percentage of birth is a function of incomes. In biology, the concept of function is the work off the body, which is also used in sociology and anthropology. For example, it has been said that 
people's personalities is somehow the function of their civilization.

Functionalism is the examination of any social act or any identity, considering the relationship that it has with the whole society. For instance, the study of social custom is complete if its relationship with economy, politics, family, religion, is considered. Hence, this theory is known as a holistic hypothesis and a hypothesis of usefulness. This vision, especially usefulness is a factor which has caused this theory to face multiple criticisms (Farbod, 2009, 120).

Malinofski has defined functionalism as follows: Function is to meet a need by an act whose purpose is to identify the mutual relationships between the elements forming a whole in order to identify a social association. Malinofski, unlike Dorkim and Radcliff Brown who have paid attention to the society and social systems, emphasize individuals' expectations in the society. The most important element of anthropology, which has received a lot of attention from Malinofski, is culture. He invented a special analysis method for culture, and he taught it to his students. The main feature of Malinowski's method is that it is holistic. He considers culture as a whole and states that different parts of culture are the elements that form a whole, which have mutual effects. Hence, he believes that habits, beliefs, identities, thoughts form culture; and the examination of culture must be based on the identification of their functions (Haman, 120).

\subsubsection{Main features and properties of functionalism}

"In general, it is acceptable that functionalism is a macro approach for examining social phenomena, especially for choice. Indeed, as it was mentioned earlier, thinkers tried to connect this macro approach to the experimental and micro examination in order to make it practical: in fact, the meaning of functionalism is very simple. A whole is a combination of elements, i.e. elements that have formed it and cooperate to maintain it even though both the elements and the whole may change. Such a linear description might be used for a family, a government, a living creature, a thinking creed, a philosophy, an identity, or a society. The idea of a whole outside of the elements of a whole requires elements, and elements require a whole, which connects sociological functionalism with many other thoughts and turns it into a pattern theory (Skidmore, 1993, 139).

In functionalism, there are central concepts such as function, structure, integrity, balance, and values (Bashirieh, 2007, 84).

Considering the above-mentioned, what is useful for our discussion on functionalism is to ask, "What are the cultural anthropology aspects in oral literature of people in Esfarayen, and how many of them are there?" considering functionalism, it must be made clear that what function this type of literature has for the society, and what need it meets, and what is the essence of this need. Another concept which is taken from function unity is public functionalism, i.e. if the society functions well according to a whole, then all elements forming it will have their own functions.

A third concept is called function analysis of function necessity, based on the idea that everything is useful for the function of whole, so it is necessary to maintain the present status and let everything be the way they are. Hence, social changes guarantee a necessary balance, and as a result, they do not pay attention to history (Yusefizadeh, 1997, 167).

For the term "function", different meanings have been presented in different areas. For example, in an official system, biology, mathematics, and so forth, function has different meanings (Tavasoli, 2000, 48).

\subsubsection{Diffusionism}

Based on diffusionism, in order to identify the characteristics of a society, we must study the cultural history of that society, considering its relationships with other societies. Since oral literature is oral, it needs examinations, and we can understand that the number of their different elements in different cultures result from four main reasons, as follows:

1) Migration

2) Similar environmental conditions

3) Historical closeness

4) Connotation (Rouh-al-Amini, 2000, 118).

Therefore, it is possible that oral literature will range from east to west or south of Iran, and even northeast countries to Esfarayen and vice versa; and this has affected the shape and structure of oral literature in Esfarayen.

Theorists of diffusion studied geographical distribution, migration, and cultural features; and they believed that cultures were collections of features possessing histories and statuses. In this theory, it is assumed that because inventions are limited, most cultures are taken from few centers. In the late $19^{\text {th }}$ century and in the early $20^{\text {th }}$ century, when Tyler and Morgan's evolutionism theory was approved by many researchers, diffusionism theories were put forward in different parts of the world; hence, three doctrines came into existence: English, German, and American diffusionism (Erikson \& Nilsson, 2007, 77). 


\subsubsection{Interpretivism}

Although folklore ruling today's life is different from the folklore with which our ancestors lived, it is part of our heritage that has been changed to a form that is usable for today's life. It is also likely that a folkloric behavior will be forgotten in a period of time, based on circumstances. But in the next periods and with a change in conditions, it will be reactivated in the new society. Therefore, the interpretation and content analysis is an important step to understanding public culture. Because people who live the present are unfamiliar with the dimensions and angles of their ancestors, and they cannot clearly understand of available messages in this section of culture. Culture is a set of meanings which is understood and interpreted through symbols and signs. Hence, in order to understand it, we need to analyze symbols. Clifford Girtz considers culture to be a symbol of concepts which have mutual contact. He believes that the understanding of a culture in all dimensions is impossible, that it must limit itself to understanding part of small and accessible wholes, and that it must consider its function as just part of a big whole which is formed gradually. He called his method interpretive anthropology. By ignoring structuralism, he focuses on the analysis of meanings and symbols from a local perspective (Asgari Khanghah \& Kamali, 2001, 261).

Myths, Beliefs, shapes, and colors present in oral literature of people in Esfarayen have been examined in terms of regional artistic and aesthetics and cryptanalysis values. Therefore, the author sees a relationship between the function of oral literature of people in Esfarayen with people's lives in Esfarayen; in this paper, he focuses on the obvious and latent functions of oral literature.

\section{Analysis of Findings}

\subsection{Oral literature of people in Esfarayen}

Since oral literature of any tribe or nation or a group of people is taken from people's needs and geographical interests, we can say that people's culture and art is considerably affected by geography, religion, history, and environmental conditions. Since Esfarayen is located in Khorasan, a big historical province with strong civilization and cultural background and with myths, especially North Khorasan, it is full of oral literature like creeds, customs, vocals, lullabies, music, dances based on the memorials of heroes, agriculture, livestock, and religious traditions. Because Esfarayen has experienced the history of Islam full of ups and downs, especially Shia and the eighth Imam (Imam Reza), it has experienced religious effects in most customs and beliefs. The kingdom of Qaznavis, and political, native, and cultural challenges facing people in Esfarayen have had big and profound impacts on Esfarayen.

\subsection{Common proverbs in Esfarayen}

Turkish Examples:

1) Dâ?da ki galdi bâyda ki yi qoldi

He who was in the mountains, came; and he kicked out those who were in the gardens.

2) âya minân âya si ni tâtimz

A man who mounts a horse does not recognize his own father.

3) kur kuri tâpar,sow,čuquri

A blind person searches and finds a blind person, and water searches and finds wells.

4) qêsâs qâlmiz qiyâmat

Vengeance does not remain there until doomsday

5) rahmat galsun zur miqurtan

Wolves are much better.

Farsi examples:

- You are a hard-working man, you are a hard-working woman, you have a better life.

- Give water to a naughty donkey, get your money. Working and earning money is not something to evade.

- My husband can be ugly as long as he makes money.

- Those people who put their hope in their neighbors go to bed hungry.

Local proverbs in Esfarayen in Karmanji dialect (speaker: Reza Gharshi, born in Esfarayen)

1) âdami xâm tama do jiyo xo ha ya har do ži xâlina

People who are avaricious have two pockets both of which are empty. 
2) Âdam šâx va $r$ dê xina

You grow a horn (i.e. you get very surprised)

3) xêzân tâ na dê giri dê šir nâdi

Babies stay hungry if their mothers do not feed them with milk.

4) yek nê leštana ka la dê porsi mâlâ kad xodi li ku

Someone did not find way into a village, he asked for the address of the lord's home.

Local proverbs of Esfarayen in Tati dialect: (speaker: Hamid fallahi, born in esfarayen)

1) kowš laxdouz pašna nêdara

The shoes of shoemakers do not have heels.

2) zêndegi sêzana vakadân

Life is like a pin and a store room of straw

3) harči kišti derâv mên

You can harvest anything that you have cultivated.

4) atiš joyê xâdiš siyâ mane

Fire blackens its place (liars are discovered)

5) kâr ê xob do mozd dara

A good job has two salaries (i.e. people pray for them in addition to paying to them)

\section{Legends, Stories, Fables, and Folktales in Esfarayen}

Another subject in oral literature of Esfarayen is exclusive to incidents and events that are divided into two parts: old and contemporary. This division is indeed exclusive to events that are described in the form of folktales and legends; and the second section refers to contemporary stories of characters and locals in Esfarayen, and finally stories that have been written by native authors. Both histories and both sections are in the realm and interpretivism of Clifford and Girtz, which have the capability to do symbolic interpretation. Ecology interpretations and based on the usage of symbols, signs, and emblems present in people's oral literature in Esfarayen, such as Abbasgholi's eternal character, locusts, The Lord and the people, Shabash customs, Shoja-al-Doleh, Khan Muhammad Pahlavan, Golden Shoe, Beautiful Girl, Puma, Horse Tail, The Girl's hair, and so forth.

\subsection{Story of Locusts}

In the old days, the attacks of locusts to villages were a very disastrous incident happening to helpless villagers and farms. When locusts started their attacks, everything was destroyed. Farmers who looked forward to their crops were witness to locusts eating their crops. And animals died from lack of provender. From the factors of famine in 1942, 1941, 1955 (when people had to pay 1 Quran for each kernel of wheat), we can refer to lack of rain and locust attacks to farms. Villagers in Esfarayen traditionally fried eggs for locusts and asked the locusts to eat the eggs and go away. When Naseral-Din Shah was king of Ghajar, locusts attacked farms in a May. One of Abbasgholi Agha Roshani's (founder of Abbas Abad village in Esfarayen) workers came over to him and informed him that: locusts have attacked your Paliz, and many of them are stuck in Kharkhaneh. What do should we do? The old farmer expected the khan to say: feed the locusts with fried eggs and ...

But Khan ordered: Burn the whole Kharkhaneh to the ground. "Fire", the old man said. He who neither dare to turn down the order of Khan nor to burn the locusts decided to take his Lord's order and went to hedge with a torch in his hand.

When he reached the hedge and stood in front of the locusts, he turned to the locusts and politely said:

Hello locusts, I have been sent to you by Abbasgholi Agha.

I am supposed to burn you.

He, who was afraid that a black and evil fate was waiting for him because of this insult, said that Abbasgholi Agha was in charge of the act and considered Abbasgholi Agha to be committing a sin. Bushes burned and thousands of locusts turned into ash.

The old man returned to the village and waited for his the karma of his brutal act.

Some days later, Abbasgholi Agha became sick and went to Mashhad for cure. Two days later, when he reached 
Soltan Abad, he became worse and died the next day. When the news of his death reached the ears of people of Abbas Abad, they said: this is the result of the locusts' curse.

\subsection{Shabash Traditions}

Wedding ceremonies of Kurds in Khorasan and Esfarayen are one of the most beautiful and happiest customs. This kind of ceremony has different stages. Here, we describe some of them including Shabash. In the afternoon of the first day of the wedding, when drums and surena players play local music, 50 to 100 people (girls and boys) dance on a dance floor which is called "Gavand" by Kurmanjs. The old and young, in colored clothes and beautiful jewelry, dance to happy drum music in a circle.

New brides and engaged girls participate in the dance program with colored veils on their heads and faces in order to pay their parents and relatives respect.

In the dance circle, there is an articulate old man and an articulate old woman. First, the chief of the tribe or the owner of the wedding (the groom's father) performs Shabash and gives money to the old man in Gavand as the start of the program.

The old man holds the money up so that everybody around Gavand sees the money. Then, he shouts: People, watch, watch. The old woman inside the circle asks: what's up? What's up? The old man loudly says: It is a golden egg. It is a golden egg. The old woman asks: Whose egg is it? It belongs to Parviz Beig Khorasakani. The old woman asks: Who is Parviz Beig?

Old man replies, "Parviz Beig is Rostam Beig's son. He is the son of Bahman Beig Khorasakanloo.

Old woman: Who is the Shabash for? For who? Who does it go to?

Old man: It goes to the daughter of Bahram Khan Sarkanloo.

The people in the ceremony loudly say: Hooray to Parviz Beig Khorasakanloo, hooray to the girl of Sarkanloo. Then, the old woman takes the Shabash from the old man and moves it up and down in his hand and shows it to everybody. After that, she goes over to the bride and puts the money in her coat or in her veil. If Shabash is in a silk cloth, she ties it to the arm of the bride, and loudly says: their receptions may be broad and held in the square; they may receive lots of gifts from God; their house may be full of children.

The Shabash program continues until all men and women who are dancing receive Shabash. They buy things that they like, using the money that they get in the wedding ceremony.

\section{Prayers and Curses in Esfarayen (Curse in Turkish Dialect in Esfarayen)}

In this section, the author has done field studies through interviews, observations, and cooperative observations. Interviews have been done with elderlies who are known as local mentors in this research; and a considerable number of prayers, curse, and quotations, have been recorded.

Speaker: Leila Alipour

Birthplace: Safi Abad village

Living place: Esfarayen; age: 41

1) gêt kê xêir 0 bara nabini

I hope you will not see good days in your life.

2) gêt kê dêrê nâq larên qêrmêz ulmasan

I hope your nails will never turn red (I hope you will never get married).

3) gêt kê javânmarg ulan

I hope you will die at a young age.

4) idolasan

I hope you will die at a young age.

5) gizlâr gurnan gurmisan

I hope will never be a bride.

People in Esfarayen find it really important to wish no marriage or death at young age for those who do bad things to them. Because marriage is one of the best events in a person's life according to oral literature of Esfarayen. They see single middle-aged people as bad and cursed people.

Curse in Kurmanji dialect 


\title{
Speaker: Reza Moradi
}

\section{Age: 59}

Birthplace and living place: Esfarayen

1. bê harka sarâtân dabêgar

I hope you will have cancer.

1- I hope your eyes will turn white.

2- bê harka nêy nak da sovyra nave

I hope your nails will never turn red.

In Esfarayen, Kurmanjis wish offensive people death and loss of marriage more.

Prayer in Kurmanji dialect

1- xodâyâ xodâvandâ oqêr vênâvaga

I wish them good destiny.

2- xodâyâ kê to ruyi bad nêvini

I hope you will never have bad day.

3- xodâyâ kê xazânê viyân vâjara dêl viyâng

I hope you will always be happy with your children.

4- xodâyâ xodâvandâ gêvâjganâ haran sar xânê mane xovâ xayr mêr bova

I hope these girls will happily go their own homes.

As you can see, there are many positive prayers in Esfarayen. Therefore, it can be inferred that marriage is one of the main pillars of the society and families in Esfarayen.

Music, songs, and vocals in Esfarayen

Local vocals for wedding ceremonies with Turkish dialect in Esfarayen

Speaker: Somayeh Ghorbani - Age: 37 - Birthplace and living place: Esfarayen

\author{
galin galin nâr galin \\ êl âyâqi duz gaalin \\ yadi uqul êstarêm \\ birun da gira galin \\ yalin galin na gatrib \\ ušdata soqât gatrib \\ bir ozun amradi \\ birvâr dolattadi \\ biêr gasâ dêyladi \\ Bride, bride, bride \\ Your hands and feet are beautiful \\ We want seven boys from you \\ We want one girl from you \\ Our bride has come \\ What has she brought \\ She has brought three souvenirs \\ She is going to have a long life \\ She has brought wealth with herself \\ She has a short tongue when talking to her mother-in-law
}

People of Esfarayen benefit from the hidden cultural and social sides of these poems by singing them in wedding parties. The poems above are considered as musical poems in the culture of people in Esfarayen. In terms of cryptologie, figures are noticeable too. The number "three" is an inseparable part of their culture. "Three times, three souvenirs, three sons, it is not ok until we have reached the third time, all of which are part of oral literature in Esfarayen, whose cultural structure shows that they belong to the period before Islam.

"Naneh Gol Mohammad" vocal

Gol Mohammad Kalmishi was from Milanloy tribe in Esfarayen; after different events in June, 1947, he was killed by Mohammad Reza Shah's military. Nomadic artists in Sabzevar have written the following poem from Golestan, the mother of Gol Mohammad Kalmishi: 
Naneh Gol Mohammad's white ewe are shaved, and carpets are made with them

I told you many times not to cut your black hair

I told you many times not to go to the Dehno

I told you many times not to act rebellious, I told you not to make friends with Al-Daghi

I told you to be friends with Al-Daghi

Al-Daghi is food and water for you, but they will take your life, Naneh Gol Mohammad

Al-Daghi is naughty and he is counting bullets for you

Where is your room, where is your fire place, where are your barrater brothers?

You are not going to help yourself to your eggs

I pray for you Naneh Gol Mohammad

I told you a hundred times not to act rebellious, do not make friends with Al-Daghi

\begin{abstract}
asbâyê sefidê xâlâli nanê gol mohamad hamê rabârê kardê qâli nanê gol mohamad hamê rabârê kardê qâli nanê gol mohamad bardê bari aldâqi nanê gol mohamad mišâyê sêfidê xâlxâli nanê golmohamad pašmâšuno konam qâli nanê gol mohamad sad bâr goftam hamči nakon nanê golmohamad zolfâyê siyâ qêyči nakon nanê gol mohamad sad bâr goftam daxu naro nanêgol mohamad bê râhê dahanê naro nanêgol mohamad sad bâr goftam mašo yâqi nanêgol mohamad dusti makon bâ aldâqi nanê gol mohamad aldâqi nuno âbêtê nanê gol mohamad âxar qâtêl ê junênêtê nanê gol mohamad aldâqi kê qêrêšmâlê nanê gol mohamad gulê tofang mêšmârê nanêgol mohamad ku otâqêt ku ojầqêt nanêol mohamad ku brârâyê qolčomâqêt nanê gol mohamad toxmê morqâyê lâyê nunêt nanê gol mohamad âxar našod nuš ê junêt nanê gol mohamad glllê mêdam dê sangarêt nanêgol mohamad amniyêhâ poštê sarêt nanêgol mohamad sad bâr goftam yâqi naro nanê gol mohamad rafiq ê aldâqi naro nanê gol Mohamad
\end{abstract}

The interviewee, Vali Allah Sirghani took a trip to Partan village in 2014. He was blind in his childhood and he is 62 years old now. He explains how he learned the poem "Naneh Gol Mohammad": we used to collect opium in a farm owned by a man called Shokr Allah Khaan Roshani. One day, a teenage boy called "Shakoo" who was a Kurd in Milanloy came to Partan. He sang Naneh Gol Mohammad song; Shokr Allah liked the song. He called me and said: Shakoo will sing the song one more time, and then you should sing it. If you sing it correctly, I will give you 40 Man of wheat. But if you sing it incorrectly, I will slap you in the face twice. I said, "One time is not enough." "I sing two times and you give me 30 Man." Shokr Allah Khan said, "No, that is out of the question. One time, and I will give you 40 Man. Then he turned to Shakoo and told him to sing the song. When Shakoo was done, he turned to me and said, "Vali, start." All workers had gathered around us, waiting to see me being slapped. But I sang the song correctly.

Shokr Allah Khan was very happy; then he stood up and kissed me, and gave me 40 Man of wheat. He also gave 40 Man to Shakoo. As the history of this writing was examined in this chapter, Tats in Esfarayen were attacked and killed by Mongolians, Uzbeks, and Afghans; hence their culture and customs has been forgotten, and no special sign of them are left. But other inhabitants of Esfarayen such as Kurds and Turks possess special culture and customs which are mentioned in this section:

In some villages of Esfarayen, sometimes heavy rain does not allow anybody to work and causes the Tum to become bigger than usual or to become decayed, so farmers' struggles and money are wasted. Therefore, a Khorde Tabi ceremony is held. In order to perform it, several children gather together. One of them ties a sweep to a long stick and stands at the beginning of a line. Some of them grab a copper pan or a can and play music with them. And several people hold dried rice stems at the start of farming season when farmers start plowing, based on customs like when they take their ploughingox to paddy; and on the first day, after some hours of plowing, they return home. Home owner pours walnuts, sugar, or coins over the heads of his cows, or he breaks eggs on the hoofs of his cows. Walnuts are symbols of big seeds of rice which they hope to harvest. According to traditions, they feed their animals with a fist of last year's crops from a bag that hangs from the ceiling. But in Tombijar, when crops are in danger of getting dried, ceremonies are held carefully.

Among women in Esfarayen, it is the custom to implant a young branch of blossoms after cultivation. This lucky plant which brings growth and verdure is famous as the bride of Tombijar. Sometimes, they put eggs over their heads. To bring luck to the young plant, they ask a new bride or a Seyed to start. After re-weeding, among female farmers, it is the custom to implant a green branch of alder on one of the walls of Rice Crete. They wish the cluster good growth. Most locals are Shafiite Sunni. Women still wear local clothes. In Kharjgil village, people speak Taleshi dialect, and most of them are Shafiite Sunni. Considering a 4000-year culture, the Taleshi tribe possesses its own special culture, all of which influence vocals. 
Within studies and results obtained from findings, the author believes that most people in Esfarayen wish to get married; and most of their curses include staying single and death for those who are offensive. These signs result from a special attention to proliferation, dynamism, and spiritual investment in the culture of marriage in Esfarayen.

According to Clifford Girtz, such prayers or curses or the characters present in stories and legends come from the serious presence of religions in people's oral cultures. Therefore, we can consider the cultural behaviors of people in Esfarayen to be the realm of religious anthropology being studied and analyzed.

\section{Discussion and Conclusion}

Due to migrations of tribes such as Turks of Azerbaijan, Tats, and Kurmanjis to Esfarayen, it possesses a wide range of oral cultures in conversational literature, customs, traditions, lullabies, superstitions, vocals, stories, folktales, proverbs, and music. Despite the dialectical and cultural differences, people of Esfarayen are close-knit and perform their customs and traditions.

What is interesting in this research is that oral literature is completely tied to the lives and customs of people in Esfarayen. For instance, religious and national ceremonies and celebrations are performed using specific oral literature, which requires us to understand that people in Esfarayen possess a rich culture; and they have held a direct connection between their culture and customs with oral literature.

Findings show that oral literature of people in Esfarayen, in addition to a historical and mythical base, owns a legendary essence based on the culture of North Khorasan and the west of Iran.

In most vocals, prayers are said more for marriage than for other wishes. And curses are mostly related to staying single and death for offensive people. Therefore, it can be said that, in oral culture of people in Esfarayen, marriage is of great importance. Findings have shown that women of Esfarayen sing vocals and songs which make them distinctive. Making traditional foods have helped women to be interdependent and cooperative; especially when they have fallen out, gatherings for making foods help them to reunite and reconcile. Foods in Ramadan and other celebrations do not just have an obvious purpose, i.e. not just offering votives in Ramadan and on the day of Imam Ali's martyrdom, or in Moharram, but they it has hidden functions which include friendship and reconciliation among women.

In most customs and oral literature of people in Esfarayen, there are hidden functions, and other parts of Iran only have obvious functions.

The results obtained from the present research show that women have a big share in oral literature of Esfarayen. Therefore, half of people's lives in Esfarayen are based on women's knowledge, emotions, thinking, and patience. In addition, children possess a certain share of oral literature, which is mostly seen in childish games. Men's share of oral literature is seen both in agriculture and in livestock and other traditional professions. The rest of oral literature belongs to people of any age and race.

Finally, people of Esfarayen are happy with a dynamic and reliable history, trying to make a living.

\section{References}

Erikson, H., Fin Sievert, N. (2007). The History of Anthropology (from beginning until today), Translated by Ali Bluk Bashi, Gol Azin Press., Tehran.

Skidmore, W. (2006). Theoretical thinking in sociology, Translated by Ali Mohammad Hazer et al., Qom, Institute of Islamic Culture and Science.

Bashirieh, H. (2007). State of Wisdom, Tehran, Modern Science Press.

Panouf, M., Perrin, M. (2007). Anthropology Culture, Translated by Asghar Asgari Khanghah, $2^{\text {nd }}$ edition, SAMT Press, Tehran.

Tavasoli, Gh.A. (2008). Theories of sociology, SAMT Press, Tehran.

Rouh Al-Amini, M. (2005). Introduction to Anthropology Culture, $8^{\text {th }}$ edition, Tehran, Attar Press.

Tayeb Osman, M. (1991). Translated by Ata Allah Rahbar, Anahita Press, Cultural Heritage Organization.

Asgari Khanghah, A., Sharif Kamali, M. (2001). General anthropology, Tehran, SAMT Press.

Farbod, M.S. (2009). Anthropology theory and schools.

Journal of Iranian Popular Culture, Issues 7 and 8, Y. 85 and 86.

Fakouhi, N. (2007). History of ideas and theories of anthropology, Tehran, Ney Press.

Jafari, M. (2012). Research on oral literature (children's book of the month), Articles number 91 and 92. 